\title{
The effect of enzyme preparations and lecithin in feed on the biological value of broiler mean
}

\author{
B.S. Kaloev ${ }^{1 *}$, M.O. Ibragimov ${ }^{2}$, V.V. Nogaeva ${ }^{1}$
}

${ }^{1}$ Gorsky State Agrarian University, 362040, Vladikavkaz, 37 Kirov Street; ${ }^{2}$ Chechen State University, 32 Aslanbek Sheripov Street, Grozny, Russian Federation,

*Corresponding Author E-mail: bkaloev@yandex.ru

Journal of Livestock Science (ISSN online 2277-6214) 12: 155-160

Received on 18/2/21; Accepted on 21/4/21; Published on 29/4/21

doi. 10.33259/JLivestSci.2021.155-160

\begin{abstract}
The biological value of meat is determined by the level of essential amino acids in protein, as well as the amount of unsaturated and saturated fatty acids in lipids. These indicators may vary depending on the biologically active substances that enter the body of the bird with the feed. The article analyzes the results of studies on broiler chickens to study the effect of the enzyme preparations Sanzaym, Sanfayz 5000 and lecithin on the biological value of the resulting meat. The research was carried out in the State Unitary Enterprise Breeding Reproductor "AchkhoyMartanovsky" of the Chechen Republic (Latitude: $43^{\circ} 11.3982$ 's. w. Longitude: $45^{\circ} 17.0238^{\prime}$ w. d.) on broiler chickens of the ROSS-308 cross. The duration of the studies was 45 days. The experiment was conducted on 4 groups of day-old chickens: 1 control and 3 experimental. As the main diet, mixed feed is used, prepared from corn, barley, wheat, sunflower cake of local production with the addition of animal feed and a special premix. This diet was used in feeding the control group of birds. For the livestock of the 1 experimental group, the studied enzyme preparations were added to the main diet, at the rate of $100 \mathrm{~g} / \mathrm{t}$ of feed. For the livestock of the 2 experimental group, the main diet was enriched with lecithin, at the rate of $10 \mathrm{~g}$ per $1 \mathrm{~kg}$ of mixed feed. For the livestock of the 3 experimental group, all 3 biologically active drugs were included in the diet, in the same amounts. It was found that the studied preparations improved the amino acid and fatty acid composition of broiler meat. Optimization of protein metabolism in the body of broilers of the experimental groups contributed to a significant increase in the concentration of the essential amino acid tryptophan in their meat from 353.3 to $366.5 \mathrm{mg} / \%$. The improvement of lipid metabolism is confirmed by an increase in the content of mono - and polyunsaturated fatty acids of muscle tissue, which indicates a higher biological value of broiler meat of the experimental groups.
\end{abstract}

Keywords: enzymes; lecithin; broiler chickens; biological value 


\section{Introduction}

The high productive qualities of modern highly productive poultry crosses are not fully manifested without the use of biologically active drugs, in particular enzymes that contribute to a more complete digestion and better assimilation of the nutrients of the diet. The use of multienzyme complexes, providing better digestion of non-starch polysaccharides and hard to digest proteins contained in the plant components of animal feed for poultry, improves quantitative and qualitative productive performance of broilers grown (Baeva et al., 2011; Zipkin \& Kolobova, 2013; Ibragimov \& Kaloev, 2018; Ibragimov \& Kaloev, 2020; Kaloev \& Khadaeva, 2011; Kaloev \& Chertkoev, 2017; Kaloev \& Ibragimov, 2017; Kaloev et al., 2017; Tmenov et al., 2014; Chernyshkov, 2019; Selle et al., 2010; Kaloev et al., 2019).

The authors note the dependence of the quality indicators of broiler chicken meat on the quality characteristics of muscle tissue fat. A positive effect on lipid metabolism is observed when phospholipids, in particular lecithin, are used in poultry feeding. At the same time, there is an improvement in productive indicators, which makes it possible to obtain better and safer livestock products (Aydinyan, 2015; Kairov et al., 2019; Kaloev \& Ibragimov, 2020; Kaloev et al., 2020).

The purpose of the research was to study the possibility of increasing the biological value of broiler meat, as a result of the inclusion of enzyme preparations and lecithin in their diet.

\section{Materials and Methods}

Location of study

Objects and methods of research. Scientific work on studying of influence of enzyme preparations Sansim, Santis 5000 and lecithin, on the biological value of meat of broiler chickens held at GUP Breeding farm "Achkhoy Martan" of the Chechen Republic (Latitude: $43^{\circ} 11.3982$ 's. w. Longitude: $45^{\circ} 17.0238^{\prime}$ w. d.) and was a part of the scientific and economic experiment according to the scheme presented in figure 1.

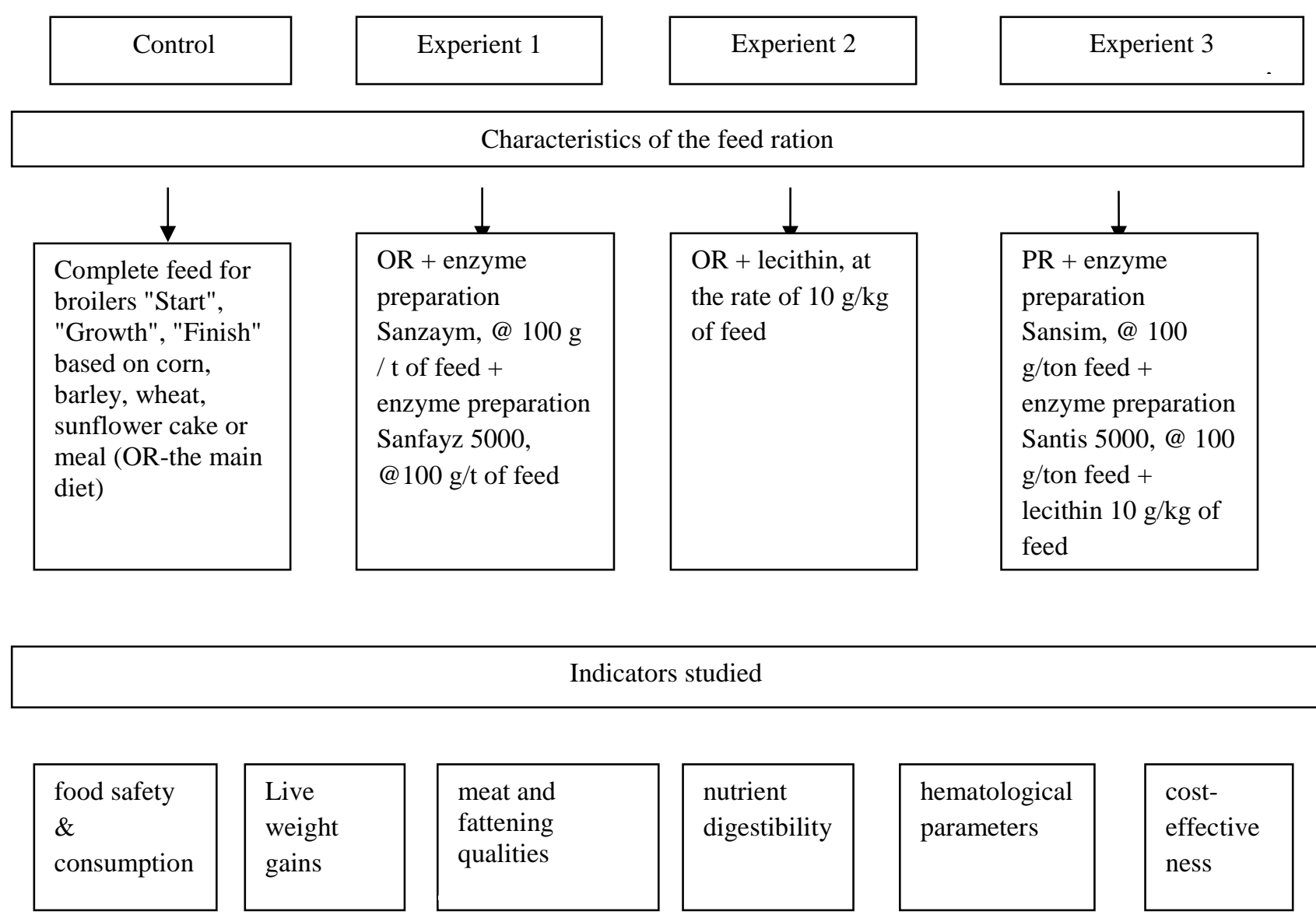

Fig 1. Scheme of scientific and economic experience 
The studies were carried out on broiler chickens of the cross "ROSS-308, raised from a day to 45 days of age. In the course of the experiment, 4 groups of daily chickens were formed, each with 100 heads. As the main diet, full-fledged mixed feeds were used, prepared with the use of corn, barley, wheat, sunflower cake of local production.

Table 1. Composition and nutritional value of feed for broiler chickens

\begin{tabular}{|c|c|c|c|}
\hline \multirow{3}{*}{ Components, $\%$} & \multicolumn{3}{|c|}{ Feed type and feeding period } \\
\hline & «Start» & «Growth» & «Finish» \\
\hline & 1-14 days & 15-28 days & $29-45$ days \\
\hline Corn & 40 & 44 & 47 \\
\hline Barley & 8 & 8 & 8 \\
\hline Wheat & 16 & 13 & 13 \\
\hline Sunflower/soy cake & 20 & 19 & 17 \\
\hline Feed yeast & 5,5 & 5,5 & 4,5 \\
\hline Fishmeal & 6 & 5 & 4 \\
\hline Animal feed fat & 2 & 3 & 4 \\
\hline Table salt & 0,3 & 0,3 & 0,3 \\
\hline Tricalcium Phosphate & 1,2 & 1,2 & 1,2 \\
\hline Premix & 1,0 (P5-1-89) & 1,0 (P5-1-89) & 1 (P6-1-89) \\
\hline \multicolumn{4}{|l|}{ Per $100 \mathrm{~g}$ of mixed feed contains: } \\
\hline - $\quad$ metabolic energy, kCal & 308,00 & 316,00 & 325,00 \\
\hline crude protein, $\mathrm{g}$ & 23,97 & 22,55 & 19,10 \\
\hline crude fat, $\mathrm{g}$ & 6,82 & 7,91 & 6,60 \\
\hline - $\quad$ crude fiber, $g$ & 4,80 & 4,78 & 4,40 \\
\hline calcium, $\mathrm{g}$ & 1,04 & 1,04 & 1,02 \\
\hline - $\quad$ phosphorus, $g$ & 0,74 & 0,70 & 0,70 \\
\hline - $\quad$ sodium, $\mathrm{g}$ & 0,17 & 0,16 & 0,18 \\
\hline - $\quad$ lysine, $\mathrm{g}$ & 1,33 & 1,24 & 1,09 \\
\hline - $\quad$ methionine + cystine, $\mathrm{g}$ & 1,05 & 0,92 & 0,83 \\
\hline
\end{tabular}

In addition to this compound feed, the studied preparations were introduced into the poultry diet of the experimental groups. Enzyme preparations Sanzaym and Sanfayz 5000 are developed by specialists of the Chinese firm "Wuhan Sunhy Biology Co., Ltd" and are made by LLC "Company Agros" Yekaterinburg. "Cansim" - a comprehensive tool for mixed rations, obtained by bacterial synthesis. The composition of "Sanzaym" includes four active enzymes: xylanase-at least 12,000 K-u/g, beta-glucanase-at least $4000 \mathrm{G}-\mathrm{u} / \mathrm{g}$, mannanase - at least $100 \mathrm{M}-\mathrm{u} / \mathrm{g}$, cellulase-at least $2000 \mathrm{C}-\mathrm{u} / \mathrm{g}$; filler-corn starch. "Santis 5000" a preparation on the basis of phytase (myo-Inositolhexaphosphate phosphohydrolase), obtained by bacterial synthesis. The minimum activity of dry "Sunfayz" is 5000 $\mathrm{FE} / \mathrm{g}$, the filler is corn starch.

Lecithin is a common name for a phospholipid-dominated lipid complex that meets the established requirements. Phospholipids are substances contained in the cells of all living organisms that perform vital functions related to the regulation of metabolic processes and the protection of cell membranes. Being a part of cell membranes, phospholipids provide their regeneration, influencing the biological activity of membrane proteins and receptors, play a crucial role in the activation of enzymes, regulate numerous metabolic processes, including the transformation of substances of a fatty nature, providing lipid metabolism.

In the course of the scientific and economic experience, all the main zootechnical indicators were carefully taken into account, including indicators that characterize the meat quality and biological value of meat in the laboratory of the Research Institute of Agricultural Ecology of the Gorsky State Agrarian University (NII AE). In particular, in the pectoral muscle, the biological value of the protein was determined by the ratio of the amount of the essential amino acid tryptophan to the substituted one-oxyproline (GOST 34132-2017. The method is based on acid hydrolysis of the protein until its complete breakdown into its constituent amino acids, followed by chromatographic determination of the mixture on an automatic liquid amino acid analyzer to identify the composition and determine the mass fraction of individual amino acids).

In view of the additives in the feed of the phospholipid preparation lecithin in the average samples of muscle tissue, according to GOST 7702-74, the fatty acid composition of lipids was determined. 
The efficiency of growing broilers is determined not only by the use of complete feed in their feeding, but also by their cost, due to the use, if possible, of feed components of local production. The complete compound feeds used in the research and production experiment included corn, barley, wheat, and sunflower cake produced in the region, as well as animal feed and mineral fertilizing. In order to provide poultry with trace elements, vitamins and individual amino acids, a special premix was introduced into the feed, depending on the growing period. During the period of our research on broiler chickens, the farm used differentiated three-phase feeding with three different types of compound feed.

In each feeding phase, the experimental bird received a complex of nutritious, mineral and biologically active substances in accordance with the existing feeding standards, which is confirmed by the given formula of compound feeds.

At the same time, the presence of a significant amount of grain components indicates a high content of difficult-to-digest substances in the feed, for additional effects on which the studied enzyme preparations and lecithin were used.

\section{Results}

The biological value of poultry meat, first of all, is determined by the fullness of its proteins, that is, the content and ratio of essential amino acids in them. Tryptophan and threonine are considered the most deficient amino acids in the human diet, so their content is taken as a unit and all other amino acids are calculated based on them.

The study of the quality indicators of the obtained meat products was carried out by determining the biological usefulness of the pectoral muscles by calculating the protein-quality indicator.

Table 2. Biological usefulness of the pectoral muscles broiler chickens

\begin{tabular}{|l|c|c|c|}
\hline \multicolumn{1}{|c|}{ Group } & $\begin{array}{c}\text { Tryptophan, } \\
\mathrm{mg} / \%\end{array}$ & $\begin{array}{c}\text { Oxyproline, } \\
\mathrm{mg} / \%\end{array}$ & $\begin{array}{c}\text { Relationship } \\
\text { Tryptophan:hydroxyproline }\end{array}$ \\
\hline Control & $353,3 \pm 2,1$ & $43,6 \pm 0,2$ & 8,1 \\
\hline 1experimental & $361,7 \pm 2,2 *$ & $43,4 \pm 0,2 * *$ & 8,3 \\
\hline 2 experimental & $361,3 \pm 1,9 *$ & $43,3 \pm 0,3 * *$ & 8,3 \\
\hline 3 experimental & $366,5 \pm 2,1 * *$ & $43,1 \pm 0,2 * *$ & 8,5 \\
\hline
\end{tabular}

Note: $*$ - $\mathrm{p} \geq 0.95, * *-\mathrm{p} \geq 0.99, * * *-\mathrm{p} \geq 0.999$.

It was found that due to the action of the studied drugs, there was a more intensive accumulation of tryptophan $(361.7-366.5 \mathrm{mg} / \%)$ in the chest muscles of the broilers of the experimental groups, with a slight decrease in the content of oxyproline. The protein-quality index, determined by the ratio of tryptophan and oxyproline in the pectoral muscle, in the control group, was 8.1 units. In the experimental groups, it increased to 8.3 - 8.5, exceeding the control indicator by 0.2-0.4 units, which is a confirmation of the increase in the biological value of broiler meat that received the enzyme preparations Sanzaym, Sanfayz 5000 in combination with lecithin. However, the nutritional value of poultry meat is not only limited to its nutritional value and protein content, it is also determined by the amount of fat and the ratio of individual fatty acids.

For further study of the quality indicators of meat, it is interesting to study the qualitative characteristics of muscle tissue fat, for which the fatty acid composition of the dry matter of the muscle tissue of broiler chickens of the experimental groups was determined.

Unsaturated fatty acids, especially polyunsaturated ones, play a special role in the body of animals and poultry, as they are essential fatty acids, and are very active chemicals. These include linoleic, linolenic, arachidonic, and eicosapentaenoic fatty acids. Their significance is determined by the fact that linoleic and arachidonic fatty acids belong to the omega- 6 family $(\omega-6)$, and linolenic and eicosapentaenoic acids belong to the omega -3 family $(\omega-3)$. Their lack in the diet of fattened poultry can lead to a decrease in live weight gains and a deterioration in their meat qualities. From this point of view, a certain increase in the content of polyunsaturated fatty acids in products, in this case broiler meat, is desirable, since it leads to an increase in their ratio to saturated (replaceable) fatty acids. To characterize the fatty acid composition of muscle tissue, Table 3 shows the composition of lipids of the dry matter of the leg muscles of broilers of the experimental groups. It was found that in the samples of the leg muscles of the experimental groups, more polyunsaturated fatty acids were found, both in total and separately, compared to the control. At the same time, there is a decrease in the total amount of saturated fatty acids, and in particular, palmitic.

The greatest effect on the fatty acid composition of the dry matter of the leg muscle is noted in the experimental groups in which the broilers were fed with compound feed lecithin, which belongs to the group of phospholipids. Due to its effect on lipid metabolism, the ratio of unsaturated to saturated fatty acids in the muscle tissue of broilers of the 2 experimental group was 1.92, and in the 3 experimental group even 1.97, while in the control-only 1.62 . 
Table 3. Fatty acid composition of leg muscle dry matter lipids, $\%$

\begin{tabular}{|c|c|c|c|c|}
\hline \multirow{2}{*}{ Fatty acids } & \multicolumn{3}{|c|}{ Group } \\
\cline { 2 - 4 } & Control & experiment 1 & experiment 2 & experiment 3 \\
\hline The amount of fatty acids & 100,0 & 100 & 100 & 100 \\
\hline Saturated & 38,16 & 37,41 & 34,23 & 33,72 \\
\hline including palmitic & 36,02 & 35,04 & 32,16 & 31,57 \\
\hline Monounsaturated & 39,73 & 40,06 & 42,89 & 42,71 \\
\hline including oleic acid & 39,24 & 39,72 & 42,38 & 42,33 \\
\hline Polyunsaturated & 22,11 & 22,53 & 23,39 & 23,57 \\
\hline including linoleic acid & 20,42 & 20,66 & 21,06 & 21,14 \\
\hline Linolenic acid & 0,38 & 0,46 & 0,59 & 0,62 \\
\hline Arachidonic acid & 0,98 & 1,03 & 1,28 & 1,30 \\
\hline Eicosapentaenoic acid & 0,33 & 0,38 & 0,46 & 0,51 \\
\hline The ratio of unsaturated to saturated & 1,62 & 1,67 & 1,92 & 1,97 \\
\hline The ratio of palmitic and oleic acids & 0,91 & 0,88 & 0,76 & 0,74 \\
\hline
\end{tabular}

These indicators allow us to speak about a higher biological value of the pectoral muscles of the broilers of the experimental groups, in comparison with the control. Another indicator of the biological usefulness of muscles in terms of lipid composition can be the ratio of individual fatty acids, and in particular palmitic, as the main representative of saturated fatty acids, and oleic, as the main representative of monounsaturated fatty acids. This indicator is therefore, its decrease from 0.91 in the control group to $0.88-0.74$ in the experimental groups confirms the positive effect of the studied drugs on the biological usefulness of leg muscle lipids.

The main content of the polyunsaturated fatty acid linoleic acid, lipids leg muscles of the experimental groups surpassed the control group $0.24-0.72 \%$, and the total content of polyunsaturated fatty acids $-0.42-1.46 \%$.

\section{Discussion}

The calculation of the protein-quality index of broiler chicken meat, which characterizes its biological value, showed maximum effectiveness when the studied enzyme preparations Sanzaym and Sanfayz 5000 and lecithin were included in their feed diet, which is largely due to the optimization of carbohydrate and protein metabolism.

Comparison of the data on the fatty acid composition of broiler meat shows that the studied preparations generally have a positive effect on the accumulation of the most valuable, unsaturated fatty acids. However, it is noticeable that the effect of the enzyme preparations Sanzaym and Sanfayz 5000, was less significant, compared to the effect of the phospholipid lecithin. This is probably due to the fact that phospholipids (lecithin) regulate numerous metabolic processes, including the transformation of substances of a fatty nature, providing lipid metabolism (Baeva, 2011; Aidinyan, 2015; Kairov et al., 2019).

Conclusion

In general, it can be stated that when including in mixed feeds prepared on the basis of corn, barley, wheat, sunflower cake of local production, enzyme preparations Sanzaym and Sanfayz 5000, as well as lecithin, the biological usefulness of broiler meat improves, which is confirmed by an increase in the protein-quality index from 8.1 to 8.5 units and an improvement in the fatty acid composition of leg muscle lipids due to the accumulation of more unsaturated fatty acids. In this case, the best results on chickens-broilers obtained by the joint use of enzymes and lecithin in doses: Cansim - $100 \mathrm{~g} / \mathrm{t}$ feed + Senpais $5000-100 \mathrm{~g} / \mathrm{ton}$ of feed + lecithin $10 \mathrm{~g} / \mathrm{kg}$ of feed.

\section{Acknowledgements}

The authors express their gratitude to the State Unitary Enterprise Breeding Reproducer "Anchkhoy-Martanovsky" of the Chechen Republic for the opportunity to conduct research on broiler chickens. Conflict of interest Authors declare there are no conflicts of interests.

\section{References}

1) Aydinyan GT, 2015.The effect of the combined use of lecithin and L-carnitine in mixed feeds of broiler chickens with a reduced level of metabolic energy. Animal Science 9: 20-22.

2) Baeva AA, Tletseruk IR, Dzidzoeva ZG, 2011. The effect of enzyme preparations on productivity and metabolism in broiler chickens. Bulletin of the Maikop State Technological University 3: 30-33. 
3) Chernyshkov AS, 2019. Analysis of productive qualities of broiler chickens when including modern enzyme and probiotic preparations in the diet. In the collection: Innovations in food production: from animal breeding to food production technology materials of international scientific and practical conferences 242-245

4) Ibragimov MO, Kaloev BS, 2018. Conversion of feed when using enzyme preparations in the diet. Izvestiya FGBOU VPO "Gorsky GAU" 55 (2): 91-96

5) Ibragimov MO, Kaloev BS, 2020. Possibilities of increasing the activity of digestive enzymes in the body of broiler chickens. News of Gorsky state agrarian University 57(1): 50-54.

6) Kaloev BS, Ibragimov MO, 2017. Fermentnye preparaty v kormlenii broilers/ Ptitsevodstvo 8: 29-32.

7) Kaloev BS, Khadaeva RB, 2011. Ways to improve the use of nutrients in the diets of broiler chickens. News of Gorsky state agrarian University 48(1): 107-109.

8) Kaloev BS, Chertkoev GB, 2017. The effect of dry bard in combination with the enzyme preparation "Feedbest VGPro" on the digestibility and use of nutrients by broiler chickens. Perm Agrarian Bulletin. Perm 3(19): 135-140.

9) Kaloev BS, Ibragimov MO, Pskhatsieva ZV, 2017. Opportunities for improving the meat qualities of broiler chickens. Bulletin of the Ulyanovsk State Agricultural Academy 3 (39): 118.

10) Kaloev BS, Ibragimov MO, 2020. Enzyme preparations and lecithin in the feeding of broiler chickens. News of Gorsky state agrarian University 57(1): 45-50.

11) Kairov AV, Temiraev RB, Mamukaev MN, 2019. Digestibility and absorption of nutrients when included in the diet of poultry meat with biologically active drugs for detoxification of $\mathrm{T}-2$ toxin. Proceedings of the Gorsky state agrarian University 56(4): 108-113.

12) Kaloev BS, Ibragimov MO, Gogaev OK, Nogaeva VV, Albegova LH, Mouraova RH, Kokoeva AT, 2019. Effect of enzyme preparations on hematological parameters of rearing and laying hens. Research journal of Pharmaceutical, Biological and Chemical. March-April, RjPBCS 10(2): 1091 - 1097

13) Kaloev BS, Ibragimov MO, Albegova LH, Kulova FM, Kadzaeva ZA, Nogaeva VV, 2020. Effect of enzyme preparations "Sanzaym", "Sanfayz 5000" and lecithin on the quality of broiler meat. Journal of Livestock Science 11: 143-148.

14) Selle RN, Cadogan DJ, Ru YJ, Partridge GG, 2010. Impact of Exogenous Enzymes in Sorghum-or WheatBased Broiler Diets on Nutrient Utilization and Growth Performance. International Journal of Poultry Science 9(1): 53-58.

15) Tmenov ID, Kaloev BS, Nogaeva VV, 2014. The effect of the enzyme preparation Phytase on the slaughter parameters of broiler chickens. News of Gorsky state agrarian University 51(3): 102-106.

16) Zlepkin DA, Kolobova TS, 2013. Qualitative indicators of broiler chicken meat when used in the rations of ginger cake in combination with enzyme preparations. Izvestiya Nizhnevolzhskogo agrouniversitetskogo kompleksa: Naukaivysshego professional obrazovanie 4 (32): 185-188. 